\title{
Sch 213766, A Novel Chemokine Receptor CCR-5 Inhibitor from Chaetomium globosum
}

\author{
Shu-Wei Yang, Ronald Mierzwa, ${ }^{\text {a } J o s e p h ~ T e r r a c c i a n o, ~}{ }^{\mathrm{b}}$ Mahesh Patel, ${ }^{\mathrm{c}}$ Vincent Gullo, ${ }^{\mathrm{d}}$ \\ Nicole Wagner, Bahige Baroudy, ${ }^{\mathrm{e}}$ Mohindar Puar, Tze-Ming Chan, Min Chu ${ }^{\mathrm{b}}$
}

Received: May 11, 2007 / Accepted: July 24, 2007

(C) Japan Antibiotics Research Association

\begin{abstract}
A novel fungal secondary metabolite, Sch 213766 was isolated from the fungal fermentation broth of Chaetomium globosum as the chemokine receptor CCR-5 inhibitor and shown to be the methyl ester of the previously described tetramic acid Sch 210972 on the basis of UV, MS and NMR spectral data analyses. Sch213766 exhibited an $\mathrm{IC}_{50}$ value of $8.6 \mu \mathrm{M}$ in the CCR-5 receptor in vitro binding assay.
\end{abstract}

Keywords anti-HIV, CCR-5 inhibitor, Chaetomium globosum, structure elucidation

Acquired immunodeficiency syndrome (AIDS) pandemic, which is caused by the type 1 human immunodeficiency virus (HIV-1) infection, has become one of the leading causes of death worldwide, and the number one cause in Africa. According to the recent report on AIDS epidemic update from UNAIDS (a joint United Nation program on HIV/AIDS) and WHO (World Health Organization), an estimated 34.1 47.1 million people were infected with HIV, 3.6 6.6 million became newly infected with HIV, and 2.9 3.5 million AIDS patients died at the end of 2006 [1]. The current standard medical treatment for HIV infected individuals called highly active antiretroviral therapy or HAART consists of three approved antiretroviral drugs, typically two reverse transcriptase inhibitors and one protease inhibitor to suppress HIV infection and reduce morbidity and mortality. Although HAART has proven effective to reduce viral load in patients with continuous dosing for over three years, this drug combination approach has not yet illustrated the capability of complete viral elimination from an infected individual. In addition, longterm toxicity and adverse drug-drug interactions of commercially available anti-HIV drugs are major concerns in medical treatments [2]. Furthermore, the emergence of viral resistance to protease and reverse transcriptase inhibitors has been reported due to the increasing use of antiretroviral agents [3]. Therefore, searching for effective anti HIV-1 infection agents with new mechanisms of action has become an urgent need. Recent studies indicated that binding to specific, cell surface co-receptors is an essential process before HIV-1 enters the targeted cells of the immune system. The chemokine receptor CCR-5 on macrophages, monocytes and T-cells, which belongs to the super family of seven-trans-membrane G-protein coupled receptors (GPCRs), has been identified as the surface co-receptor with the $\mathrm{CD}_{4}$ molecule for viral entry [4]. The endogenous ligands of the CCR-5 receptor are the
S.-W. Yang, M. Chu (Corresponding authors), R. Mierzwa, J. Terracciano, M. Patel, V. Gullo, N. Wagner, B. Baroudy, M. Puar, T.-M. Chan: Schering-Plough Research Institute, 2015 Galloping Hill Road, Kenilworth, New Jersey, 07033, USA, E-mail: shu-wei.yang@spcorp.com,min.chu@cubist.com

a Present address: Wyeth Pharmaceuticals, 401 North Middletown Rd., Pearl River N.Y. 10965

\footnotetext{
${ }^{\mathrm{b}}$ Present address: Cubist Pharmaceuticals, Inc. 65 Hayden Avenue, Lexington, MA 02421

${ }^{\mathrm{c}}$ Present address: SMP International LLC, 42 Brentwood Drive, Verona, NJ 07044

${ }^{\mathrm{d}}$ Present address: Cetek Corporation, 260 Cedar Hill Street, Marlborough, MA 01752

${ }^{\text {e }}$ Present address: Phytobiotech Inc. 500 Cartier Blvd. West, Laval, Quebec H7V 5B7, Canada
} 


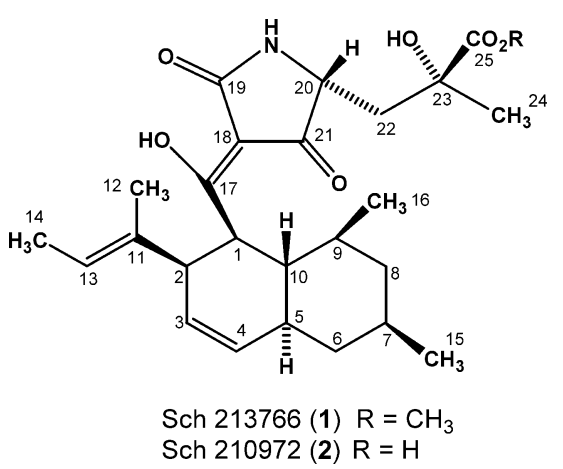

$\beta$-chemokines MIP- $1 \alpha$, MIP- $1 \beta$ and RANTES [5]. Functional inhibition of the chemokine receptor CCR-5 is expected to block viral entry as an initial stage of HIV-1 infection. Therefore, discovery of potent and selective CCR-5 antagonists would potentially lead to a new antiHIV drug [6].

To search for novel CCR-5 inhibitors as potential leads for development, a high throughput screening (HTS) campaign of extracts derived from various sources including actinomycets, fungal or plant species has been launched utilizing the CCR-5 membrane binding assays. Previously, the screening of these extracts had led to the discovery of two secondary metabolites as selective CCR-5 inhibitors produced by a fungal culture designated as Chaetomium globosum (Mer-0229) [7]. This report described the discovery of the methyl ester of Sch 210972 designated Sch 213766 (1), its production, isolation, structure elucidation, and biological activity.

The producing culture was collected and isolated from sterilized leaves of evergreen plants collected in Tucson, Arizona, USA. It was characterized as a fungus, $C$. globosum, based on morphological studies and deposited in the American Type Culture Collection with the accession number ATCC 74489.

The fermentation broth (4.0 liters) was adjusted with concentrated $\mathrm{HCl}$ to $\mathrm{pH} 2$, and then extracted with 12 liters of EtOAc. After removal of solvent under reduced pressure, the crude extract $(8.0 \mathrm{~g})$ was partitioned between hexane : EtOAc: $\mathrm{MeOH}: \mathrm{H}_{2} \mathrm{O}$ with $5 \%$ acetic acid, $8: 2$ : $5: 5$. The CCR-5 active concentrated complex from upper phase portion $(800 \mathrm{mg})$ was chromatographed by normal phase HPLC (YMC semi-preparative PVA-Sil column $30 \times 250 \mathrm{~mm}$ with guard $30 \times 75 \mathrm{~mm}, \mathrm{~S}-5,2.0 \% \mathrm{MeOH}$ in $n$-butyl chloride, $24 \mathrm{ml} /$ minute, $\mathrm{UV}=295 \mathrm{~nm}$ ) to obtain crude 1 . The mixture was further purified through bioassayguided fractionation by reverse phase HPLC (YMC semipreparative ODS column, $20 \times 250 \mathrm{~mm}$ with a guard column $20 \times 50 \mathrm{~mm}, \mathrm{~S}-5,70 \sim 100 \%$ acetonitrile in $\mathrm{H}_{2} \mathrm{O}$
Table $1{ }^{1} \mathrm{H}$ - and ${ }^{13} \mathrm{C}-N M R$ Data of Sch $213766(\mathbf{1})^{\mathrm{a}}$

\begin{tabular}{|c|c|c|}
\hline$\#$ & ${ }^{1} \mathrm{H}$ & ${ }^{13} \mathrm{C}$ \\
\hline 1 & $3.95 \mathrm{dd}(8.0,7.0)^{\mathrm{b}}$ & $45.2^{c} d^{d}$ \\
\hline 2 & $3.00 \mathrm{dt}(8.0,1.0)$ & $48.7 \mathrm{~d}$ \\
\hline 3 & 5.66 brs & $126.2 \mathrm{~d}$ \\
\hline 4 & 5.66 brs & $134.3 d$ \\
\hline 5 & $1.82 \mathrm{~m}$ & $38.4 d$ \\
\hline 6 & $0.95,1.90 \mathrm{~m}$ & $42.4 \mathrm{t}$ \\
\hline 7 & $1.63 \mathrm{~m}$ & $33.2 \mathrm{~d}$ \\
\hline 8 & $0.83,1.66 \mathrm{~m}$ & $46.8 \mathrm{t}$ \\
\hline 9 & $1.39 \mathrm{~m}$ & $35.1 \mathrm{~d}$ \\
\hline 10 & $1.40 \mathrm{~m}$ & $39.9 d$ \\
\hline 11 & - & $138.2 \mathrm{~s}$ \\
\hline 12 & $1.59 \mathrm{brs}$ & $16.5 q$ \\
\hline 13 & $5.19 \mathrm{dq}(6.5,1.0)$ & $122.0 \mathrm{~d}$ \\
\hline 14 & $1.50 \mathrm{brd}(6.5)$ & $13.8 q$ \\
\hline 15 & $0.91 \mathrm{~d}(6.5)$ & $22.8 \mathrm{q}$ \\
\hline 16 & $0.84 \mathrm{~d}(6.5)$ & $20.2 \mathrm{q}$ \\
\hline 17 & - & $194.7 \mathrm{~s}$ \\
\hline 18 & - & $100.9 \mathrm{~s}$ \\
\hline 19 & - & $176.6 \mathrm{~s}$ \\
\hline 20 & $3.80 \mathrm{dd}(10.0,2.5)$ & $60.7 d$ \\
\hline 21 & - & $192.9 \mathrm{~s}$ \\
\hline 22 & $\begin{array}{l}1.75 \mathrm{dd}(14.0,10.0) \\
2.22 \mathrm{dd}(14.0,2.5)\end{array}$ & $43.0 \mathrm{t}$ \\
\hline 23 & - & $75.3 \mathrm{~s}$ \\
\hline 24 & $1.46 \mathrm{~s}$ & $28.0 q$ \\
\hline 25 & - & $176.9 \mathrm{~s}$ \\
\hline $\mathrm{OCH}_{3}$ & $3.77 \mathrm{~s}$ & $52.9 q$ \\
\hline
\end{tabular}

a Measured at $400 \mathrm{MHz}$ in acetone- $d_{6}$, chemical shifts in ppm from TMS. ${ }^{b}$ Coupling constants in $\mathrm{Hz} .{ }^{\circ}$ Recorded at $100 \mathrm{MHz}$ in acetone- $d_{6}$, chemical shifts in ppm from TMS. ${ }^{d}$ Multiplicity was determined by APT data.

with a linear gradient in 15 minutes, $12 \mathrm{ml} /$ minute, $\mathrm{UV}=$ $220 \mathrm{~nm})$ to afford pure $\mathbf{1}(20 \mathrm{mg})$ as gum-like material. 1 was soluble in acetone, EtOAc, acetonitrile, $\mathrm{MeOH}$ and $\mathrm{CH}_{2} \mathrm{Cl}_{2}$, but was insoluble in hexane and $\mathrm{H}_{2} \mathrm{O}$.

Mass spectral data generated from LC/MS experiments using electrospray ionization (ESI) mode showed $\mathrm{M}+\mathrm{H}^{+}$at $\mathrm{m} / \mathrm{z} 460$ indicating the molecular weight of 459 for $\mathbf{1}$, which was also confirmed with FAB-MS data. The molecular formula was deduced by elemental analysis; calcd for $\mathrm{C}_{26} \mathrm{H}_{37} \mathrm{NO}_{6}$ : C 67.97, $\mathrm{H} 8.06, \mathrm{~N} 3.05 \%$, found $\mathrm{C}$ $67.11, \mathrm{H} 7.88, \mathrm{~N} 3.67 \%$. UV absorption at 220 and $295 \mathrm{~nm}$ revealed the presence of a conjugation system indicating tetramic acid in 1. Absorption bands in the IR spectrum at 3407,1736 and $1655 \mathrm{~cm}^{-1}$ suggested the presence of hydroxyl, carboxyl, and carbonyl groups, respectively. The ${ }^{13} \mathrm{C}-\mathrm{NMR}$ spectrum contained 26 carbon resonances 


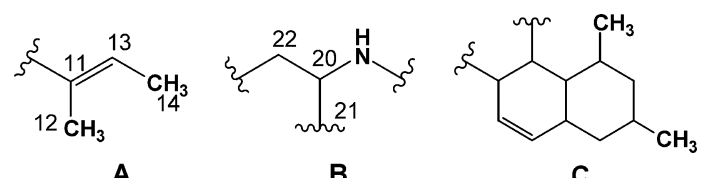

Fig. 1 Partial structure assignments of Sch 213766 (1) based on COSY and HMOC data.

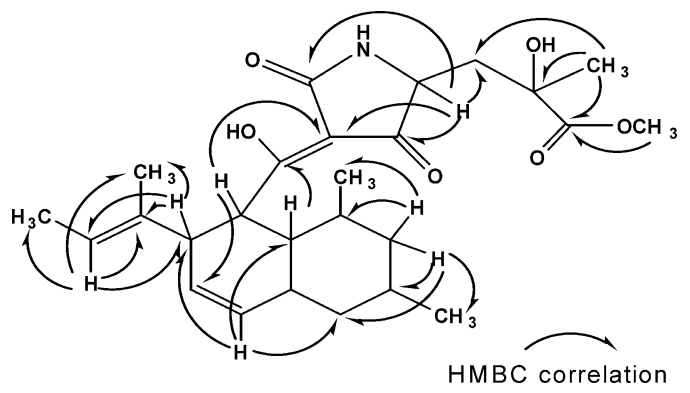

Fig. 2 Important ${ }^{1} \mathrm{H}-{ }^{13} \mathrm{C}$ long range coupling $\mathrm{HMBC}$ data of 1.

representing two carbonyl, two amide/acid carbonyl, two olefinic quaternary, three vinyl methine, one oxygenated quaternary, one nitrogenated methine, six methine, three methylene and six methyl carbons (Table 1). The ${ }^{1} \mathrm{H}-\mathrm{NMR}$ spectrum was consistent with ${ }^{13} \mathrm{C}-\mathrm{NMR}$ data showing three vinyl proton signals at $\delta 5.66(\mathrm{H}-3), 5.66(\mathrm{H}-4)$ and 5.19 (H-13), one nitrogenated methine signal at $\delta 3.80(\mathrm{H}-20)$, two allylic methine resonances at $\delta 3.95(\mathrm{H}-1)$ and $3.00(\mathrm{H}-$ 2 ), two sets of a geminal methylene doublet of doublet (AB spin system) at $\delta 2.22(\mathrm{H}-22)$ and $1.75(\mathrm{H}-22)$, one allylic methyl singlet at $\delta 1.59\left(\mathrm{CH}_{3}-12\right)$, one allylic methyl doublet at $\delta 1.50\left(\mathrm{CH}_{3}-14\right)$, two methyl singlets at $\delta 1.46$ $\left(\mathrm{CH}_{3}-24\right)$ and $3.77\left(\mathrm{CO}_{2} \mathrm{CH}_{3}\right)$ and two methyl doublets at $\delta$ $0.91\left(\mathrm{CH}_{3}-15\right)$ and $0.84\left(\mathrm{CH}_{3}-16\right)$. Further 2D-NMR analysis with ${ }^{1} \mathrm{H}-{ }^{1} \mathrm{H}$ correlation data permitted the establishment of three partial structures, A, B and C based on COSY and HMQC experiments as shown in Fig. 1. The assignments of these three fragments were accomplished by analysis of long range ${ }^{1} \mathrm{H}-{ }^{13} \mathrm{C}$ correlation data generated from $\mathrm{HMBC}$ experiment. As shown in Fig. 2, the correlations of $\mathrm{H}-13$ to $\mathrm{C}-2$, as well as $\mathrm{H}-2$ to $\mathrm{C}-11, \mathrm{C}-12$ and $\mathrm{C}-13$ indicated attachment of fragment $\mathrm{A}$ to fragment $\mathrm{C}$ at position-2. The correlation of $\mathrm{H}-20$ to $\mathrm{C}-18, \mathrm{C}-19$ and

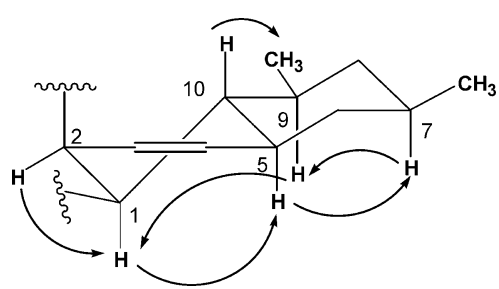

Fig. 3 Some important NOESY data of 1.

C-21 suggested the formation of a 2,4-pyrrolidine-dione ring from fragment $\mathrm{B}$ as a core unit of tetramic acid. The carbon chain extension on the methylene group $\left(\mathrm{CH}_{2}-22\right)$ attached to a hydroxyl-carboxylic bi-substituted two carbon moiety was assigned on the basis of correlations of $\mathrm{H}-24$ to $\mathrm{C}-22, \mathrm{C}-23$ and $\mathrm{C}-25$. The methyl ester functionality was assembled by analysis of the correlation of the $\mathrm{OCH}_{3}(\delta$ 3.77, s) to $\mathrm{C}-25$. The final connectivity of the decalin moiety and tetramic acid through the enol carbon $\mathrm{C}-17$ was established by $\mathrm{HMBC}$ correlations of $\mathrm{H}-1$ to $\mathrm{C}-18$, as well as $\mathrm{H}-10$ to $\mathrm{C}-17$. Thus, the structural assignments of all protons and carbons for $\mathbf{1}$ were completed, establishing $\mathbf{1}$ as the methyl ester of Sch 210972 (2), which was isolated previously from the same microorganism [7].

The relative configuration of $\mathbf{1}$ was determined by NOESY data (Fig. 3) and optical rotation data in comparison with 2 . The observation of four 1,3-diaxial couplings between $\mathrm{H}-1$ and $\mathrm{H}-5, \mathrm{H}-5$ and $\mathrm{H}-7, \mathrm{H}-7$ and $\mathrm{H}-$ 9, and H-9 and H-1 revealed the $\alpha$-orientation of these protons. The coupling between $\mathrm{H}-1$ and $\mathrm{H}-2$ further showed the same $\alpha$-configuration (equatorial) for the $\mathrm{H}-2$ proton. Moreover, observation of NOE between $\mathrm{H}-10$ and $\mathrm{CH}_{3}-9$ showed that the $\mathrm{H}-10$ proton had the $\beta$-orientation, thus forming a trans configuration at the decalin ring junction. The configurations of two chiral centers at C-20 and C-23 of 1 were established to be the same as $\mathbf{2}$, which was determined by X-ray crystallographic data analysis [7], by direct comparison of their very similar optical rotation data with $[\alpha]_{\mathrm{D}}^{25}$ value of $+33.3^{\circ}\left(c 0.1, \mathrm{Me}_{2} \mathrm{CO}\right)$ for $\mathbf{1} v s .+40.0^{\circ}$ for 2 .

1 displayed significant inhibitory activity with an $\mathrm{IC}_{50}$ value of $8.6 \mu \mathrm{M}$ in the CCR-5 membrane-binding assay. In the specificity study, $\mathbf{1}$ was also tested in the CCR-2 binding assay ${ }^{\dagger}$, and there was no inhibitory activity observed at $100 \mu \mathrm{M}$ concentration. Interestingly, as the

\footnotetext{
${ }^{\dagger}$ A high throughput screen utilizing a CCR-5 membrane-binding assay identified inhibitors of RANTES binding. This assay utilized membranes prepared from NIH 3T3 cells expressing the human CCR-5 chemokine receptor, which has the ability to bind to RANTES, a natural ligand for the receptor. In a 96-well plate format, $14 \mu \mathrm{g}$ (total protein) of membrane preparation and $0.05 \mathrm{nM}$ of ${ }^{125} \mathrm{I}$-RANTES were incubated in the presence (or absence) of compound, fraction or extract for one hour. Compounds or extracts were serially diluted over a wide range of 0.001 to $1 \mu \mathrm{g} / \mathrm{ml}$ and tested in triplicates. Reaction cocktails were harvested through glass fiber filters, and washed thoroughly. The $\mathrm{IC}_{50}$ data reported as the concentration required inhibiting $50 \%$ of total ${ }^{125}$ I-RANTES binding.
} 
methyl ester of $\mathbf{2}$, the potency of $\mathbf{1}$ decreased over 100 fold in comparison to 2 ( $\mathrm{IC}_{50} \sim 0.08 \mu \mathrm{M}$ ) as an inhibitor of CCR-5. The data strongly indicated that the free carboxylic acid group plays an important role in the receptor binding.

The novel secondary metabolite $\mathbf{1}$ belongs to the tetramic acid (2,4-pyrrolidine-dione) class of antibiotics [8]. Numerous natural occurring tetramic acids have been reported in the scientific literature including coniosetin [9], vancoresmycin [10], CJ-17,572 [11], CJ-21,058 [12], ascosalipyrrolidinone A [13], reutericyclin [14], crypotocin [15], xanthobaccin A [16], LL-49F233 [17], PF1052 [18], lydicamycin [19], MBP049 [20], equistin [21], and phomasetin [22]. Tetramic acid type antibiotics possess antimicrobial activity against various microorganisms including many resistant microbial pathogens [8]. To the best of our knowledge, $\mathbf{1}$ and $\mathbf{2}$ are the only natural tetramic acid metabolites possessing CCR-5 antagonistic activity to be reported in literature.

Acknowledgments The authors are grateful to Mr. Y-H. Ing and Mr. P. Bartner for low resolution ESI and FAB-MS data, Mr. P. Cai for optical rotation data, and Mr. G. Torraca for IR data and elemental analysis.

\section{References}

1. Global summary of the AIDS epidemic, AIDS epidemic update, UNAIDS and WHO, December 2006. www.unaids.org/en/hiv_data/

2. (a) Pillay D. Current patterns in the epidemiology of primary HIV drug resistance in North America and Europe. Antiviral Therapy 9: 695-702 (2004)

(b) Cheung PK, Wynhoven B, Harrigan PR. 2004: which HIV-1 drug resistance mutations are common in clinical practice? AIDS Reviews 6: 107-116 (2004)

(c) Pillay D, Taylor S, Richman DD. Incidence and impact of resistance against approved antiretroviral drugs. Reviews in Medical Virology 10: 231-253 (2000)

(d) Pomeranz RJ. Primary HIV-1 resistance: A new phase in the epidemic? J Am Med Assoc 282: 1177-1179 (1999)

3. (a) Pallela FJ, Delaney KM, Moornan AC, Loveless MO, Fuhrer J, Satten GA, Aschman DJ, Holmberg SD. Declining morbidity and mortality among patients with advanced human immunodeficiency virus infection. N Engl J Med 338: 853-860 (1998)

(b) Furtado MR, Callaway DD, Phair JP, Kunstman KJ, Stanton JL, Macken CA, Perelson AS, Wolinsky SM. Persistence of HIV-1 transcription in peripheral-blood mononuclear cells in patients receiving potent antiretroviral therapy. N Engl J Med 340: 1614-1622 (1999)

4. Cocchi F, DeVico AL, Grazino-Demo A, Arya SK, Gallo $\mathrm{RC}$, Lusso P. Identification of RANTES, MIP-1 alpha, and
MIP-1 beta as the major HIV-suppressive factors produced by CD8 + T cells. Science 270: 1811-1815 (1995)

5. (a) Feng Y, Broder CC, Kennedy PE, Berger EA. HIV-1 entry cofactor: functional cDNA cloning of a seventransmembrane, G protein-coupled receptor. Science 272: 872-877 (1996)

(b) Samson M, Liber F, Doranz BJ, Rucker J, Liesnard C, Farber C-M, Saragosti S, Lapoumeroulle C, Cognanx J, Forceille C, Muyldermans G, Vehofstede C, Butonboy G, Georges M, Imai T, Rana S, Yi Y, Smyth RJ, Collman RG, Doms RW, Vassart G, Parmentier M. Resistance to HIV-1 infection in caucasian individuals bearing mutant alleles of the CCR-5 chemokine receptor gene. Nature 382: 722-728 (1996)

(c) Allkhatib G, Combadiere C, Broder CC, Feng Y, Kennedy PE, Murphy PM, Berger EA. CC CKR5: a RANTES, MIP-1alpha, MIP-1beta receptor as a fusion cofactor for macrophage-tropic HIV-1. Science 272: 1955-1958 (1996)

(d) Berger EA, Murphy PM, Farber JM. Chemokine receptors as HIV-1 coreceptors: roles in viral entry, tropism, and disease. Annu Rev Immunol 17: 657-700 (1999)

6. (a) Strizki JM, Xu S, Wagner NE, Wojcik L, Liu J, Hou Y, Endres M, Palani A, Shapiro S, Clader JW, Greenlee WJ, Tagat JR, McCombie S, Cox K, Fawzi AB, Chou C-C, Pugliese-Sivo C, Davies L, Moreno ME, Ho DD, Trkola A, Stoddart CA, Moore JP, Reyes GR, Baroudy BM. SCH-C (SCH 351125), an orally bioavailable, small molecule antagonist of the chemokine receptor CCR5, is a potent inhibitor of HIV-1 infection in vitro and in vivo. Proc Natl Acad Sci USA 98: 12718-12723 (2001)

(b) Shiraishi M, Aramaki Y, Seto M, Imoto H, Nishikawa Y, Kanzaki N, Okamoto M, Sawada H, Nishimura O, Baba M, Fujino M. Discovery of novel, potent, and selective smallmolecule CCR5 antagonists as anti-HIV-1 agents: synthesis and biological evaluation of anilide derivatives with a quaternary ammonium moiety. J Med Chem 43: 2049-2063 (2000)

(c) Baba M, Takashima K, Miyake H, Kanzaki N, Teshima K, Wang X, Shirashi M, Iizawa Y. TAK-652 inhibits CCR5mediated human immunodeficiency virus type 1 infection in vitro and has favorable pharmacokinetics in humans. Antimicrob Agents Chemother 49: 4584-4591 (2005)

(d) Strizki JM, Tremblay C, Xu S, Wojcki L, Wagner N, Gonsiorek W, Hipkin W, Chou CC, Pugliesie-Sivo C, Xiao Y, Tagat JR, Cox K, Priestley T, Sorota S, Huang W, Hirsch M, Reyes GR, Baroudy BM. Discovery and characterization of vicriviroc (SCH 417690), a CCR5 antagonist with potent activity against human immunodeficiency virus type 1 . Antimicrob Agents Chemother 49: 4911-4919 (2005)

(e) Wood A, Armour D. The discovery of the CCR5 receptor antagonist, UK427,857, a new agent for the treatment of HIV infection and AIDS. Prog Med Chem 43: 239-271 (2005)

(f) Dorr P, Westby M, Dobbs S, Griffin P, Irvine B, 
Macartney M, Mori J, Rickett G, Smith-Burchnell C, Napier C, Webster R, Armour D, Price D, Stammen B, Wood A, Perros M. Maraviroc (UK-427,857), a potent, orally bioavailable, and selective small-molecule inhibitor of chemokine receptor CCR5 with broad-spectrum anti-human immunodeficiency virus type 1 activity. Antimicrob Agents Chemother 49: 4721-4732 (2005)

(g) For a recent review: Palani A, Tagat JR. Discovery and development of small-molecule chemokine coreceptor CCR5 antagonists. J Med Chem 49: 2851-2857 (2006)

7. Yang S-W, Mierzwa R, Terracciano J, Patel M, Gullo V, Wagner N, Baroudy B, Puar M, Chan T-M, McPhail AT, Chu M. Chemokine receptor CCR-5 inhibitors produced by Chaetomium globosum. J Nat Prod 69: 1025-1028 (2006)

8. Royles BJL. Naturally occurring tetramic acids: structure, isolation, and synthesis. Chem Rev 95: 1981-2001 (1995)

9. Segeth MP, Bonnefoy A, Bronstrup M, Knauf M, Schummer D, Toti L, Vertesy L, Wetzel-Raynal M, Wink J, Seibert G. Coniosetin, a novel tetramic acid antibiotic from Coniochaeta ellipsoidea DSM 13856. J Antibiot 56: 114-122 (2003)

10. Hopmann C, Kurz M, Bronstrup M, Wink J, LeBeller D. Isolation and structure elucidation of vancoresmycin-a new antibiotic from Amycolatopsis sp. ST 101170. Tetrahedron Lett 43: 435-438 (2002)

11. Sugie Y, Dekker KA, Inagaki T, Kim Y-J, Sakakibara T, Sakemi S, Sugiura A, Brennan L, Duignan J, Sutcliffe JA, Kojima Y. A novel antibiotic CJ-17,572 from a fungus, Pezicula sp. J Antibiot 55: 19-24 (2002)

12. Sugie $\mathrm{Y}$, Inagaki S, Kato $\mathrm{Y}$, Nishida H, Pang C-H, Saito T, Sakemi S, Dib-Hajj F, Mueller JP, Sutcliffe J, Kojima Y. CJ-21,058, a new SecA inhibitor isolated from a fungus. J Antibiot 55: 25-29 (2002)

13. Osterhage C, Kaminsky R, Konig GM, Wright AD. Ascosalipyrrolidinone A, an antimicrobial alkaloid, from the obligate marine fungus Ascochyta salicorniae. J Org Chem 65: 6412-6317 (2000)
14. Holtzel A, Ganzle MG, Nicholson GJ, Nicholson GJ, Hammers WP, Jung G. The first low molecular weight antibiotic from lactic acid bacteria: reutericyclin, a new tetramic acid. Angew Chem Int Ed Engl 39: 2766-2768 (2000)

15. Li J-Y, Strobel G, Harper J, Lobkovsky E, Clardy J. Cryptocin, a potent tetramic acid antimycotic from the endophytic fungus Cryptosporiopsis $c f$. quercina. Org Lett 2: 767-770 (2000)

16. Hashidoko Y, Nakayama T, Homma Y, Takara S. Structure elucidation of xanthobaccin A, a new antibiotic produced from Stenotrophomonas sp. strain SB-K88. Tetrahedron Lett 40: 2957-2960 (1999)

17. Singh MP, Zaccardi J, Greenstein M. LL-49F233 $\alpha$, a novel antibiotic produced by an unknown fungus: biological and mechanistic activities. J Antibiot 51: 1109-1112 (1998)

18. Sasaki T, Takagi M, Yaguchi M, Nishiyama K, Yaguchi T, Koyama M. (Meiji Seika Kaisha, Ltd.), Novel antibiotic PF1052 and its manufacture with Phoma species. Jpn Tokyo, Koho JP 04316578 (1991)

19. Hayakawa Y, Kanamaru N, Shimazu A, Seto H. Lydicamycin, a new antibiotic of a novel skeletal type. I. Taxonomy, fermentation, isolation and biological activity. J Antibiot 44: 282-287 (1991)

20. Furui M, Takashima J, Mikawa T, Yoshikawa T, Ogishi H. (Mitsubishi Chemical Co. Ltd.), A novel proline hydroxylase inhibitor MBP049-13 and its manufacture with Ophiobolus. Jpn Kokai Tokkyo, Koho JP 04074163 (1992)

21. Phillips NJ, Goodwin JT, Fraiman A, Cole RJ, Lynn DJ. Characterization of the fusarium toxin equisetin: the use of phenylboronates in structure assignment. J Am Chem Soc 111: 8223-8231 (1989)

22. Singh SB, Zink DL, Goetz MA, Dombrowski AW, Polishook JD, Hazuda DJ. Equisetin and a novel opposite stereochemical homolog phomasetin, two fungal metabolites as inhibitors of HIV-1 integrase. Tetrahedron Lett 39: 2243-2246 (1998) 